\title{
Paper Making Techniques in the Field of Printmaking Art Education
}

\author{
Saime Dönmezer \\ Printmaking Department \\ Faculty of Fine Arts \\ Anadolu University26470 \\ Turkey
}

\begin{abstract}
The invention of Handmade Paper is considered as an important stage in the Life Cycle Grade of Human Beings, which is in continous progress, by means of information transfer. Due to accessibility of materials and technological develeopments, paper production has reached to a good level of economy. The word paper comes from Papyrus in its roots. The Production of Paper explained in its history, today can be examined in two types: Commercial and Artistic. The aim of this paper is to learn and develop the production of artistic hand made paper with texture of plants which is used in plastic arts, and to set up a similar workshop in the Faculty of Fine Arts, to inroduce this production especially to the print making studuents would widen their perspectives, while providing a medium to work experimentally.
\end{abstract}

Keywords: Handmade Paper, plant, printmaking, Art

\section{Introduction}

Within the life cycle constantly developed by humankind, invention of paper is an important milestone which enabled powerful and accurate information transfer. As the modern technology employed and easy retrieval to multiple raw materials, paper production gains better economical conditions.

If we take a look at the paper from invention and development process; first paper type was parchment made of very thin layer of animal skin. Parchment was used even after paper spread through the globe because it was very durable. Being each and every parchment different, being hard to tear and very durable made parchment remain as documents for long period of time.

\section{History:}

Papirus was invented some 5000 years ago. Papirus is a kind of paper made of a water plants growing in the Nile Delta called Cyperus Papyrus. The plant is 4-5meter tall and Egygtian use the trunk to produce rope, basket, rattan, foot wear and boat.

Very first paper made of cellulosic fibres is accepted to be made by Ts'ai Lan in Lei Yang city of China in 105 AC. He was an official who lived there some 2000 years ago and invented the paper we use today. He boiled the tree peels for a long time, pestled the boiled peels to form a dough and filters them into a panel, dried them to become the very first paper.

In the far east to produce paper, inner fibers of paper berry tree, Chinese nettle (chinese cannabis), after year 1100 in China Bamboo Fibres and after 1521 rice pedicle and especially in Japan, fibres from gampi and mitsumata plants peels are used. Although paper production was kept as secret for a long time, it has eventually spread eastbound to Japan and to west through Silk road. In the Eastern spread Korea was arrived first and from here to Japan by a Korean Monk named Dokyo in 610 and production started in Kyoto by Seibei Mochizuki in 807. Paper production had started in Samarkand by the Paper Craftsmen enslaved in Talas war. Paper continued its journey from East to West but Samarkand had remained a major paper production center. Paper production spread in Islamic World and kept spreading to Europe. It took longer to (-a, -e yönlendirme eki olarak ,to' kullanılması gerekli değildir) in terms of production in Europe. A quick review of paper inEurope shows us that T'sai Lun's production method couldn' $t$ arrive Europe in 1000 years. The first paper in Europe could have produced as late as 1151 in Spain. Paper production crossed the Atlantic in 1690 and arrived to Canada in 1803. Especially with the invention of printing, increased demand for paper and scarcity of raw material, together with long time of production caused a search for a solution. First (bizce Firdst olarak yazilmamali) paper production machine was built in 1798. It was a simple machine to be able to produce single sheet at once. Clyndirical machine was invented by John Dickinson in 1809.Although exact date is unknown, about first decade of 18th century, French scientist Antoine Ferchault de Reaurmur had come across to a bee hive. He had started to examine thehive in the absence of bees. He had suddenly realized that the hive was made of paper. How 
come the bees made the hive without using swab? What did the bees know that humans don' $t$ ? It becomes evident that it was very simple (cümlenin yeni düzenlemesi).

After a short observation he had seen that, wasp are biting the thin boughs and rotten logs, chew them with their saliva and stomach enzimes and use in making of the hives. Reaumur, further examining bee's digestion system andsubmitted his research to French Royal Academy.

The new faith medium while Islam was spreading, the Arabic merchants of Caspian Sea Region, Middle East, Egypt and Mediterranean shores made this Chinese make very precious trade merchandise transported to Europe.

Besides the trade, Muslim Umayyad Dynasty, also reigned in Spain started paper production in Europe by the first paper production facility in Xativa, Spain in AC 10th century.

By AC 13th century, Italy would become paper production center of Europe and would produce paper, one of the most important elements of Renaissance, in better conditions.

Later in AC 15th century, Germany founded first paper production facility that can be called mass production. Gutenberg's inventon of movable printing enabled printed matter to reach out to most part of society.

There are many people who developed paper production in both raw materials and production process terms. Paper, in its early production periods it was both hard and expensive, is still not hard but expensive due to daily life of mankind.

As we briefly mentioned before, if we proceed to paper as a course in schools, we need to mention printmaking's enterance to schools as the main material is paper.

Enterance of printmaking started with departments of painting, sculpture and engraving in "Mekteb-i Sanayi-i Nefise-i Şahane" in March 3, 1883. Recognition of printmaking increased when Printing Arts Department in Faculty of Fine Arts in Anatolian University opened. After opening, with the printmaking artists from abroad and homeland gathering aroun department has became solid.

The department with course design proper to modern needs started to educate students, send and accept students from abroad. There are programs teaching traditional techniques as well as multi disciplinary courses covering modern days. Paper production course as an example of these courses was using recycled paper. Many research and projects are realized in these years passed.

Printing Encouragment Project titled "Paper Production from Plants" prepared, accepted and for making paper with the fibres from plants, Prof. Timothy Frerichs of Department of Visual Arts and New Media, USA SUNY Fredonia State University of New York came to Turkey. He tried making paper from fibres with a group of students from our department. They have achieved to very successful results.

\section{Process:}

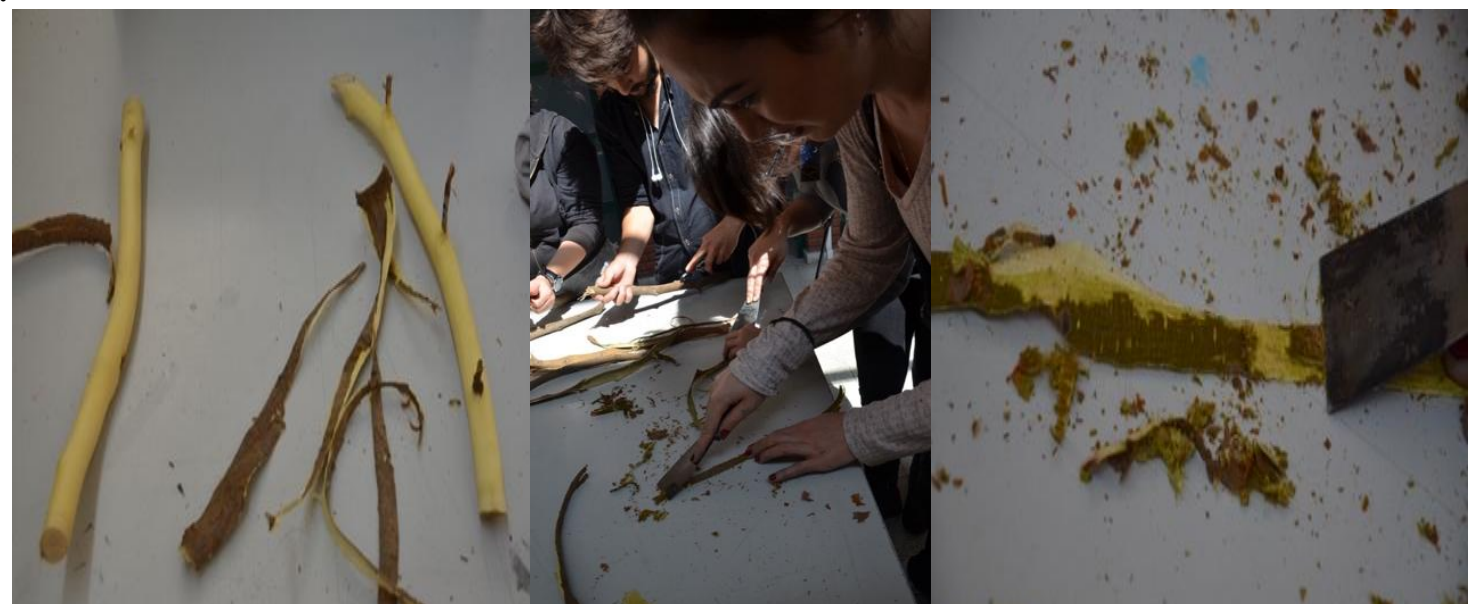

Firstly, raw material of hand made paper is broussonetia, which is rare in our country, instead general white mulberry branches collected and soaked in water for a long period. Boiling container filled with water, soaked fibres added to that water, boiled until peels separated. Fibres gathered from tree peels while keeping them moist. Fibres and left black peels are picked in separate clean water tanks. 


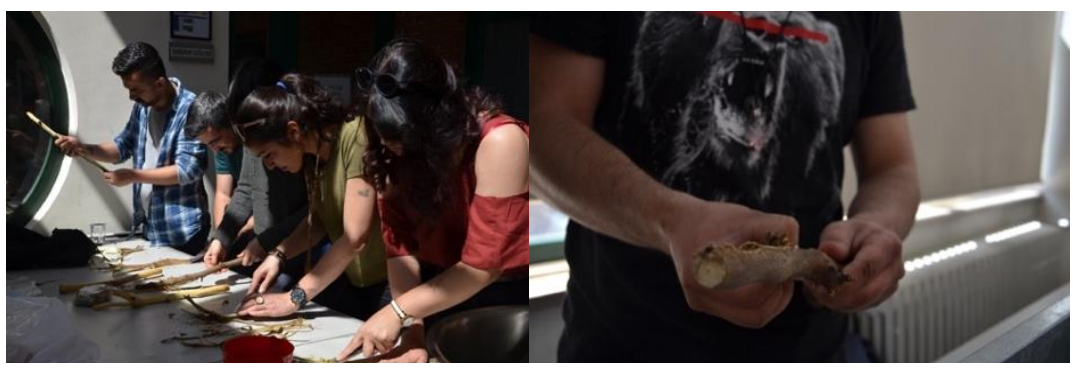

In pounding process feculence of melon size collected, extra water is drained out. In order to fibres smoothen they are pounded with a mallet and transferred to clean water container.

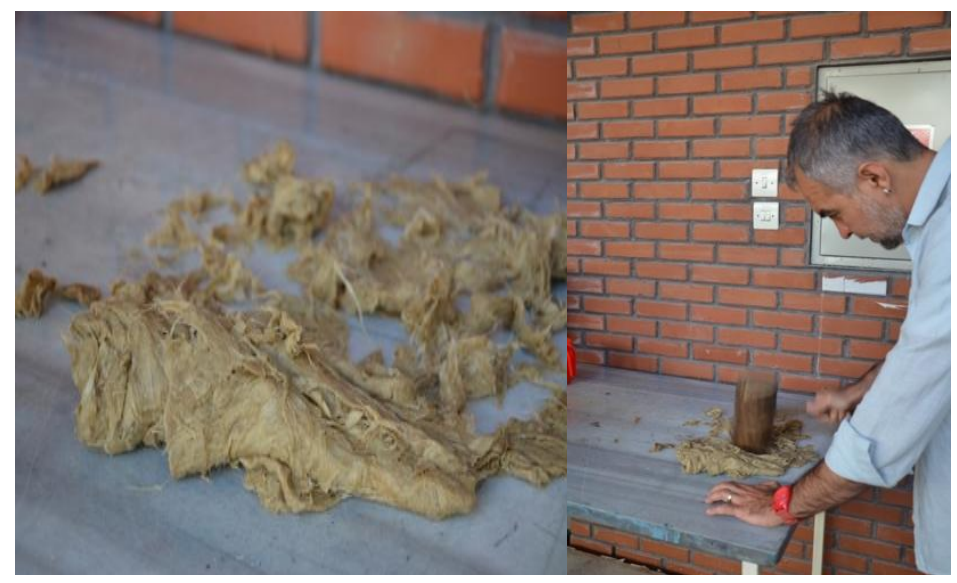

Feculence was pressed to take out excess water and transferred to fabric sheets, hanged and left to dry. Another method is to transfer the feculence onto a drier or glass surface with a brush to dry.

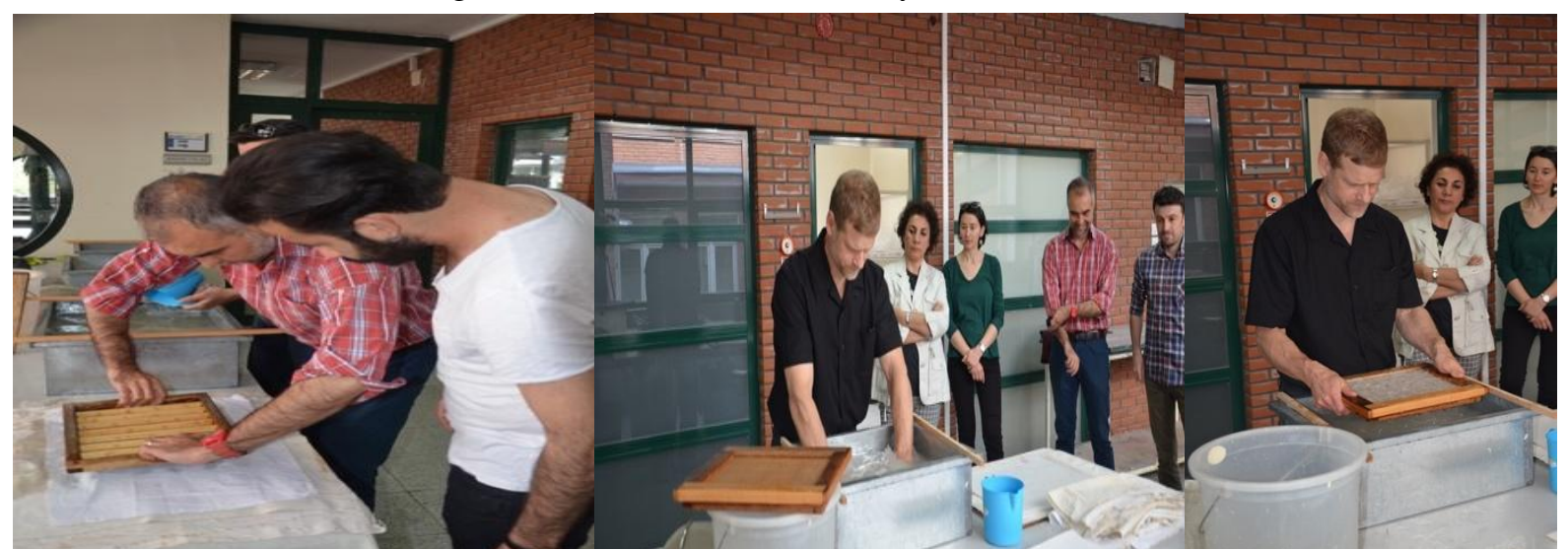

Secondly, fibers from cotton or recycled paperwere cut into $5 \mathrm{~cm}$ squares, kept in cold water for an hour and paper produced as described above method.

Western style is applied for cotton and recycled paper. Third method is from Abaka: Abaka is hard to tear when dried, therefore fibers had to be wetted before and then cut into $5 \mathrm{~cm}$ squares. Abaka is Western or Japanese style (nagashizuki)

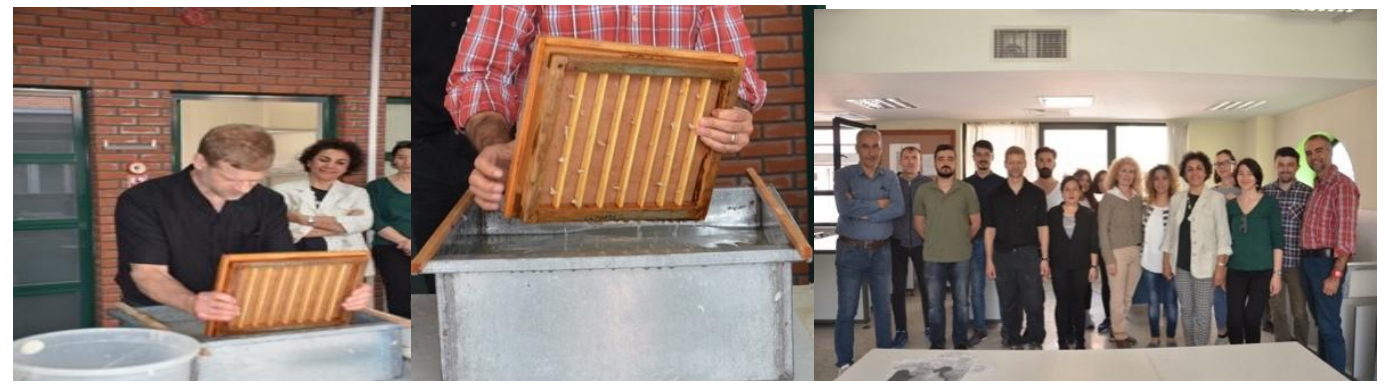


In both cases two thirds of mixer is filled with water and 4 wet paper (not apper) dough added. It is stirred for a few minutes until becomes oatmeal consistency. After transferring to a bucket rest of the feculence is processed. Feculence in the containers are taken out with both western or eastern type of strainers and left to drain out. Feculence on the strainer brought on a sheet and water was taken out by sponge and transferred on the fabric sheets. With extra water sponged out, paper sheets are left to dry. When dried out they are ready to use.

\section{Conclusions:}

There are two types of paper produced which we briefly mentioned the history and production; commercial paper and artistic paper. The purpose of our Project is to learn plant tissue and production process of paper used in plastic arts and our Fine Arts Faculty acquire that kind of workshop for itself. As a result of this kind of study; students of our faculty, especially Printied Art Department students will be able to produce the paper they need and able to open a new job opportunity.

\section{References}

Frerichs, T., (2018) Making handmade paper from plant, Workshop, Printmaking Department, Faculty of Fine Arts, Anadolu University

İbrahim Müteferrika Paper Museum, (2018) Yalova

https://www.bilgiustam.com/resimler/2008/03/12.JPG

http://www.serdarkalkan.com/kagit_nasil_yapilir.htm 